
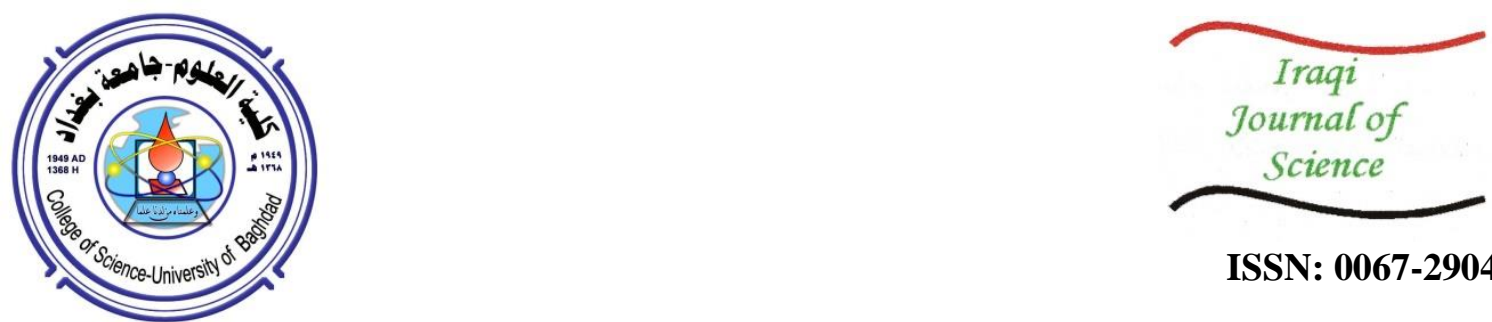

ISSN: 0067-2904

\title{
Electrochemical Deposition of Hydroxyapatite Co-Substituted By Sr/Mg Coating on Ti-6Al-4V ELI Dental Alloy Post-MAO as Anti-Corrosion
}

\author{
Haider Abdulkareem AlMashhadani ${ }^{1 *}$, Khulood Abed Saleh ${ }^{2}$ \\ ${ }^{1} \mathrm{Al}$ Rasheed University College, Dentistry Department, Baghdad, Iraq \\ ${ }^{2}$ Department of Chem., College of Science, University of Baghdad, Jaderyah, Baghdad, Iraq \\ Received: $12 / 10 / 2019$ \\ Accepted: 30/12/2019

\begin{abstract}
This work involved the co-substitution of the two bioactive ions of strontium and magnesium into the hydroxyapatite (HA) coating which was then electrochemically deposited on Ti-6Al-4V ELI dental alloy (Gr.23) before and after treatment by Micro Arc Oxidation (MAO). The deposited layers were characterized by scanning electron microscopy (SEM), energy-dispersive X-ray spectroscopy (EDS), X-ray diffraction (XRD), and Fourier transform infrared spectroscopy (FTIR). The adhesion strength of the coating layer was estimated by using pull-off adhesion test. The adhesion strength of Sr/Mg-HA on the Ti-6Al-4V ELI dental alloy after MAO treatment was $1.79 \mathrm{MPa}$, which was higher than that before MAO treatment (1.62 $\mathrm{MPa}$ ). The corrosion behavior of the alloy in artificial saliva environment at temperature ranged $293-323 \mathrm{~K}$ was assessed by means of electrochemical techniques and potentiodynamic polarization curves. The corrosion protection to the alloy at 293K was increased from $67.98 \%$ before treatment by MAO to $75.87 \%$ after treatment. The antimicrobial properties of the coated alloy were evaluated against different bacteria and oral fungi (Candida).
\end{abstract}

Keywords: Hydroxyapatite, Dental alloy, Deposition, Corrosion, Titanium alloy.

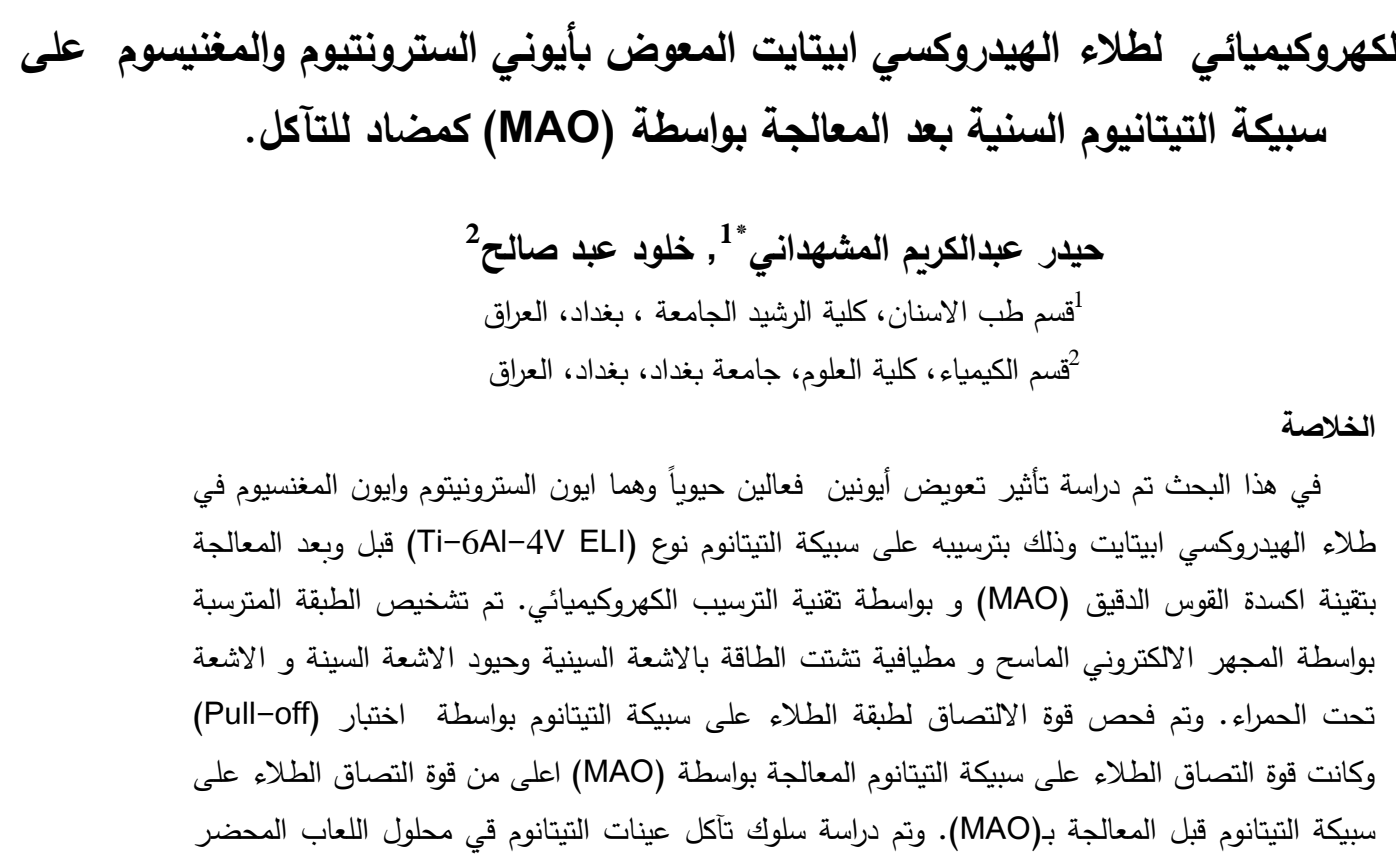




$$
\begin{aligned}
& \text { مختبرياً عند مدى حراري } 293 \text { - } 323 \text { كلفن بمتابعة منحنيات الاستقطاب لتآكل سبيكة التيتانيوم وازدادت } \\
& \text { كفاءة حماية التآكل من 67,98\% قبل المعالجة الى 75,87\% بعد المعالجة بـ(MAO) وتم دراسة الفعالية } \\
& \text { البايلوجية ضد بكتريا مختلفة و فطريات الفم. }
\end{aligned}
$$

\section{Introduction}

Micro arc oxidation (MAO) is one of the most promising techniques for dental alloy surface therapy and has subsequently been widely accepted by multiple industry branches [1]. MAO is usually used on valve materials such as $\mathrm{Al}, \mathrm{Mg}, \mathrm{Ti}, \mathrm{Ta}, \mathrm{Nb}, \mathrm{Zr}$, and $\mathrm{Be}$ to create multi-purpose wear, anticorrosion, heat-resistant dielectric, and ornamental coatings [1-4]. Titanium alloys are one of the most convenient bio-materials for dental applications because of low toxicity, superior corrosion resistance, good mechanical properties and biocompatibility with bone [5-7]. Due to the tendency of self healing it is deemed to have the highest bio-tolerance among all the currently used dental biomaterials [8].

Apatite can be deposited on dental implant surfaces because it is well accepted by living tissues, such as bone. Apatite can also promote strong bonds between tissues and dental implant surface $[9,10]$. Hydroxyapatite (HA) is a valuable bone repair and regeneration material because of its compatibility to the inorganic phase of human bone [5].

HA has been widely used as a coating material for titanium dental implants in a variety of applications. Typically, the release of $\mathrm{Ca}^{2+}$ and $\mathrm{PO}_{4}{ }^{3-}$ ions into the surrounding oral environment leads to the development of excellent interfacial strength between the implant and bone [11].

A wide range of different ions such as $\mathrm{Sr}, \mathrm{Zn}, \mathrm{Ag}, \mathrm{Mg}, \mathrm{CO}_{3}^{-2}, \mathrm{~F}$ and $\mathrm{Si}$ have been strategically incorporated into the structure of synthetic $\mathrm{HA}$, replacing $\mathrm{Ca} / \mathrm{PO}_{4}{ }^{3-}$. The substitution of ions in $\mathrm{HA}$ modifies the crystallinity and crystal size and also changes material properties, namely thermal and phase stability, solubility, surface reactivity, and ability to be absorbed [12-14]. Sr plays a key role in bone bio-mineralization by promoting the number of osteoblasts and reducing the number and activity of osteoclasts. $\mathrm{Sr}$ is particularly useful in the treatment of osteoporosis [15]. Substitution of $\mathrm{Mg}$ into HA leads to improved cell growth, anti-corrosion, and an increase in bond strength compared to unsubstituted HA coating. Mg-HA acts like Sr by improving the proliferation of osteoblast and inhibiting osteoclast activity. Incorporation $\mathrm{Mg}$ with $\mathrm{HA}$ decreases crystallinity and increases cell adhesion and bioactivity. Electrochemical deposition techniques were developed for the deposition of $\mathrm{Sr} / \mathrm{Mg}-\mathrm{HA}$ dispersed in a suitable solvent at a particular $\mathrm{pH}$. These coatings require a MAO reaction to improve the coating properties $[16,17]$.

In this work, we investigated Sr/Mg-HA coating on Ti-6Al-4V ELI dental alloy by using electrochemical deposition before and after MAO treatment. The coatings were characterized by FTIR, X-ray and SEM. Coating adhesion was measured in order to assess their surface morphologies. The biological activities for the coating against several bacteria and oral fungi were also studied.

\section{Experimental Part}

\subsection{Titanium Preparation}

Circular shape samples of Ti-6Al-4V ELI dental alloys (Gr.23) were mechanically cut with dimensions of $1 \mathrm{~cm}$ diameter and 4-5 mm thickness.

These samples were polished with emery papers in different grades $(600,800,1200$ and 2000 mesh grit) successively washed with tap water, distilled water, ethanol, and acetone, and dried with a hair drier.

Before MAO treatment, the specimens were deoxidized by $10 \% \mathrm{NaOH}$ then de-smutted by nitric acid $50 \%$. After each step, they were double rinsed with distilled water and finally with acetone [18].

\subsection{Artificial Saliva Preparation}

The reference electrolyte used was the modified Fusayama artificial saliva, according to a previously described method [19], which closely resembles natural saliva. The composition of the artificial saliva is show in Table-1, while the $\mathrm{pH}$ of this electrolyte was 6.2 [19].

Table 1-The composition of the artificial saliva

\begin{tabular}{|c|c|c|c|c|c|c|}
\hline & $\mathrm{KCl}$ & $\mathrm{NaCl}$ & $\mathrm{CaCl}_{2} \cdot \mathrm{H}_{2} \mathrm{O}$ & $\mathrm{NaH}_{2} \mathrm{PO}_{4} \cdot 2 \mathrm{H}_{2} \mathrm{O}$ & $\mathrm{Na}_{2} \mathrm{~S}_{2} 9 \mathrm{H}_{2} \mathrm{O}$ & urea \\
\hline $\mathrm{g} / \mathrm{l}$ & 0.4 & 0.4 & 0.906 & 0.69 & 0.005 & 1 \\
\hline
\end{tabular}




\subsection{Micro Arc Oxidation of Ti alloys}

For the MAO, an AC power of $150 \mathrm{~V}$ was applied for $120 \mathrm{sec}$. A titanium sample was used as an anode whereas a large titanium sheet was used as the cathode electrode in an electrolyte containing 10 $\mathrm{g} / \mathrm{L} \mathrm{KH}_{2} \mathrm{PO}_{4}$ and $0.5 \mathrm{~g} / \mathrm{L} \mathrm{KOH}$. The electrolyte temperature was kept constant at $298 \mathrm{~K}$. After the $\mathrm{MAO}$, the samples were washed with distilled water and dried at room temperature. Figure-1 shows the structure of the MAO reaction cell.

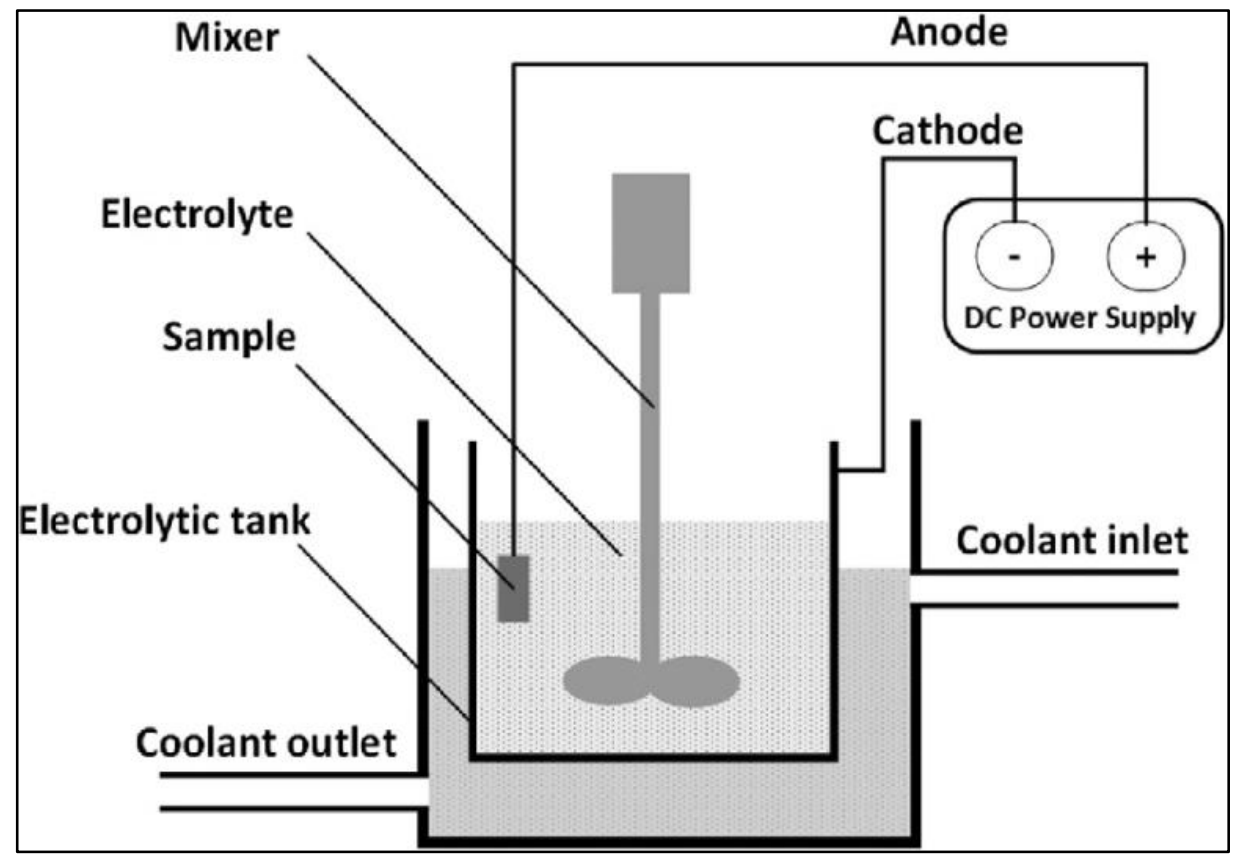

Figure 1-Micro Arc Oxidation cell [20]

\subsection{Electrochemical deposition of $\mathrm{Sr} / \mathrm{Mg}-\mathrm{HA}$}

HA co-substituted with 5\% $\mathrm{Sr}$ and $5 \% \mathrm{Mg}$ was electrochemical deposited directly on the surface of a Gr.23 alloy. The experimental ratio of $(\mathrm{Ca}+\mathrm{x}) / \mathrm{P}$ (where $\mathrm{x}=\mathrm{Sr}$ or $\mathrm{Mg}$ ) was maintained at 1.7 (molar ratio). The suspension was prepared by dissolving calcium nitrate $\left(\mathrm{Ca}\left(\mathrm{NO}_{3}\right)_{2}\right)$, strontium nitrate $\left(\mathrm{Sr}\left(\mathrm{NO}_{3}\right)_{2}\right)$ and magnesium nitrate $\left(\mathrm{Mg}\left(\mathrm{NO}_{3}\right)_{2}\right)$ in distilled water. Then, i-ammonium hydrogen phosphate $\left(\left(\mathrm{NH}_{4}\right)_{2} \mathrm{HPO}_{4}\right)$ was added and the $\mathrm{pH}$ value of the solution was adjusted to 4.4 using dilute $\mathrm{HNO}_{3}$. The electrochemical deposition of $\mathrm{Sr} / \mathrm{Mg}-\mathrm{HA}$ on $\mathrm{Gr} .23$ was conducted at room temperature on a stirrer with direct current power (DC) $(6 \mathrm{~V})$, while the time was kept for $1 \mathrm{~h}$. After deposition, the specimens were rinsed in distilled water, dried by a hair drier, and then soaked in $1 \mathrm{~mol} / \mathrm{L} \mathrm{NaOH}$ solution at $80{ }^{\circ} \mathrm{C}$ for $2 \mathrm{~h}$

\subsection{Characterization and test}

Spectroscopic analysis of the formed $\mathrm{Sr} / \mathrm{Mg}-\mathrm{HA}$ coating was investigated with FT-IR. The surface morphologies of Sr/Mg-HA coating were measured and analyzed by XRD and SEM.

The galvanostatic polarization was measured using WENKING M Lab. device (Germany). Polarization curves were achieved for the corrosion of dental titanium alloys before and after MAO treatment. The obtained polarization curves involved the cathodic and anodic regions. Extensive data could be derived from the detailed analysis of each polarization region using an extrapolated method to determine both the corrosion current density $\left(i_{\text {corr }}\right)$ and corrosion potential $\left(E_{\text {corr }}\right)$.

The $\mathrm{Sr} / \mathrm{Mg}$-HA coating was tested for antimicrobial activity by well diffusion method against pathogenic bacteria such as Gram-negative bacteria [Escherichia coli (E-coli) and Acinetobacter baumannii (A-baumannii)] and Gram-positive bacteria [Staphylococcus aureus (S-aureus) and Bacillus subtilis (B-subtilis)], and oral fungi such as Candida albicans (C-Albicans), Candida glabrata (C-glabrta), Candida parapsilosis (C-parapsiosis) and Candida tropicalis (C-tropicalis).

\section{Results and Discussion}

\subsection{Potentiostate polarization measurements}

The effect of the coating layer on the polarization curves of Gr.23 corrosion was investigated in an artificial saliva solution, at a temperature range of 293-323K before and after MAO treatment (Figure- 
2). The corrosion current density ( $i_{\text {corr }}$ ) was determined by extrapolation Tafel lines. The results of the effects of $\mathrm{Sr} / \mathrm{Mg}-\mathrm{HA}$ coated layer on the corrosion parameters before and after MAO treatment are shown in Table- 2 .

It is clear from Figure- 2 that $\mathrm{E}_{\text {corr }}$ for the uncoated and coated $\mathrm{Gr} .23$ by $\mathrm{Sr} / \mathrm{Mg}-\mathrm{HA}$ before and after MAO treatment were shifted to a more active direction with increasing temperature from (293 to 323)K. $\mathrm{E}_{\text {corr }}$ for $\mathrm{Gr} .23$ coated with $\mathrm{Sr} / \mathrm{Mg}$-HA before and after MAO treatment, at a temperature range of 293-323K, showed high values compared with the value for the uncoated Gr.23 alloy. Coating of Gr.23 by $\mathrm{Sr} / \mathrm{Mg}-\mathrm{HA}$, before and after MAO treatment, led to increase $\mathrm{E}_{\text {corr }}$ values to the noble direction. This indicates that the titanium alloy is difficult to corrode after being coated by $\mathrm{Sr} / \mathrm{Mg}-\mathrm{HA}$.
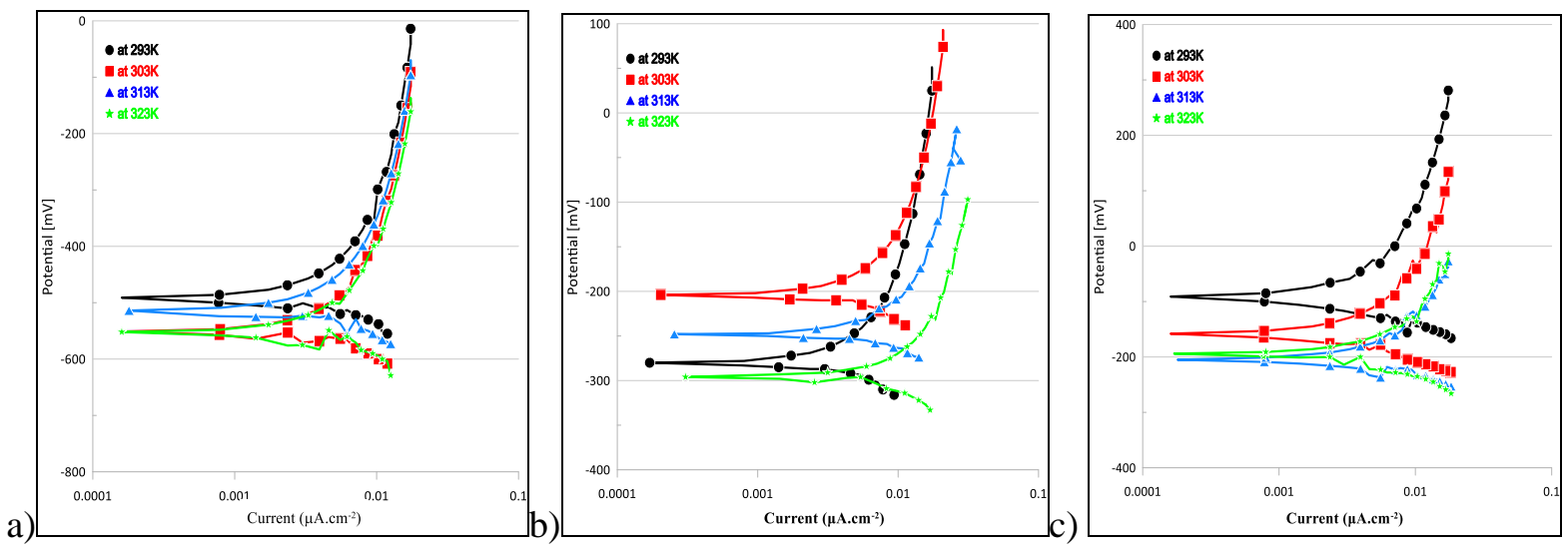

Figure 2-Polarization curves for Gr.23 a) Uncoated, b) Coated by Sr/Mg-HA before MAO and c) Coated by $\mathrm{Sr} / \mathrm{Mg}-\mathrm{HA}$ after MAO

Table 2-Corrosion parameters of coated Gr.23 before and after MAO treatment in artificial saliva at different Temperatures

\begin{tabular}{|c|c|c|c|c|c|c|c|c|c|}
\hline \multicolumn{2}{|c|}{ Temp./K } & \multirow{2}{*}{$\begin{array}{c}\begin{array}{c}\mathbf{E}_{\text {corr }} / \\
\mathbf{~} \mathbf{V}\end{array} \\
-490.5\end{array}$} & \multirow{2}{*}{$\begin{array}{c}\mathbf{i}_{\text {corr }} / \boldsymbol{\mu A} . \\
\mathbf{c m}^{-2}\end{array}$} & \multirow{2}{*}{$\begin{array}{c}\begin{array}{r}\text { bc/mV. } \\
\text { dec }^{-1}\end{array} \\
102.4\end{array}$} & \multirow{2}{*}{$\begin{array}{c}\begin{array}{c}\mathrm{ba} / \mathrm{mV} \\
\text { dec }^{-1}\end{array} \\
285.5\end{array}$} & \multirow{2}{*}{$\begin{array}{c}\begin{array}{c}\text { w.l/g. } \\
\mathbf{m}^{-2} \cdot \mathbf{d l}^{-1}\end{array} \\
0.324\end{array}$} & \multirow{2}{*}{$\begin{array}{c}\begin{array}{c}\text { P.L/ } \\
\text { mm.y }^{-1}\end{array} \\
0.0263\end{array}$} & \multirow{2}{*}{$\begin{array}{c}\mathbf{R}_{\mathbf{p}} / \mathbf{\Omega . c \mathbf { c m } ^ { 2 }} \\
10800.64\end{array}$} & \multirow{2}{*}{$\begin{array}{c}\text { PE\% } \\
-\end{array}$} \\
\hline \multirow{4}{*}{ 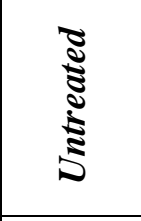 } & 293 & & & & & & & & \\
\hline & 303 & -551.2 & 3.490 & 106.1 & 391.9 & 0.374 & 0.0304 & 10388.23 & - \\
\hline & 313 & -515.9 & 3.800 & 158.0 & 400.2 & 0.412 & 0.0334 & 12943.94 & - \\
\hline & 323 & -550.6 & 3.820 & 135.3 & 495.8 & 0.516 & 0.0419 & 12082.27 & - \\
\hline \multirow{4}{*}{ 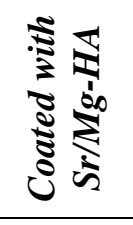 } & 293 & -281.0 & 0.970 & 11.2 & 42.6 & 0.104 & 0.0084 & 3969.90 & 67.98 \\
\hline & 303 & -204.4 & 1.110 & 12.8 & 46.9 & 0.120 & 0.0097 & 3933.61 & 68.19 \\
\hline & 313 & -248.5 & 1.580 & 19.6 & 54.2 & 0.169 & 0.0137 & 3955.92 & 58.42 \\
\hline & 323 & -295.9 & 1.760 & 63.2 & 53.5 & 0.189 & 0.0153 & 7148.14 & 53.92 \\
\hline \multirow{4}{*}{ 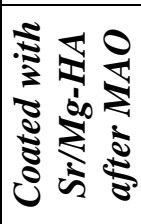 } & 293 & -92.1 & 0.731 & 41.3 & 56.5 & 0.078 & 0.0064 & 14172.56 & 75.87 \\
\hline & 303 & -158.3 & 0.873 & 38.1 & 56.6 & 0.094 & 0.0076 & 11326.17 & 74.98 \\
\hline & 313 & -204.9 & 0.910 & 33.2 & 40.0 & 0.098 & 0.0079 & 8656.68 & 76.05 \\
\hline & 323 & -193.7 & 0.974 & 38.9 & 42.1 & 0.104 & 0.0085 & 9013.51 & 74.50 \\
\hline
\end{tabular}

The data in Table- 2 show that $\mathrm{i}_{\text {corr }}$ values for Gr.23 coated by Sr/Mg-HA before MAO treatment are lower $\left(0.97\right.$ to $\left.1.76 \mu \mathrm{A} . \mathrm{cm}^{-2}\right)$ than those for uncoated $\mathrm{Gr} .23\left(\mu \mathrm{A} . \mathrm{cm}^{-2} 3.03\right.$ to 3.82). Protection efficiency (PE \%) was calculated using the following equation [21, 22]:

$$
\% P E=\frac{\left(i_{\text {corr }}\right) \mathrm{b}-\left(i_{\text {corr }}\right) \mathrm{p}}{\left(i_{\text {corr }}\right) \mathrm{b}} \times 100
$$

where $\left(i_{\text {corr }}\right) b$ and $\left(i_{\text {corr }}\right) p$ are the values of corrosion current density $\left(\mu \mathrm{A} . \mathrm{cm}^{-2}\right)$ for uncoated and protected Gr.32, respectively.

This coating resulted in a protective layer against corrosion with a PE\% value that reached to $67.98 \%$ at $293 \mathrm{~K}$. This protection was decreased with increasing temperature to reach to $53.92 \%$ at 
323K. While coating the Gr.23 alloy with $\mathrm{Sr} / \mathrm{Mg}-\mathrm{HA}$, after MAO treatment, led to a protective layer against temperature, where the PE\% have was not effected by temperature and the PE\% value ranged between 74.5 to $76.05 \%$ at temperature range of 293 to $323 \mathrm{~K}$.

Polarization near the corrosion potential $E_{\text {corr }}$ was calculated to determine the polarization resistance on the basis of the following Stern-Geary equation [23, 24]:

$$
\mathrm{R}_{\mathrm{p}}=\frac{\Delta E}{\Delta i}=\frac{b_{a} b_{c}}{2.303\left(b_{a}+b_{a}\right)} \cdot \frac{1}{i_{\text {corr }}}
$$

where $R_{\mathrm{p}}$ is the polarization resistance of the system, $\Delta E$ is the difference between the measured potential $E$ and the corrosion potential $E_{\text {corr }}, \Delta i$ is the difference between the measured current density $i$ and the corrosion current density $i_{\text {corr }}$, and $b_{\mathrm{a}}$ and $b_{\mathrm{c}}$ are the anodic and cathodic Tafel coefficients, respectively.

The polarization resistance $\left(\mathrm{R}_{\mathrm{p}}\right)$ for Gr.23 coated by Sr/Mg-HA, before MAO treatment, showed lower values compared with those for uncoated Gr.23. While coating by Sr/Mg-HA after MAO treatment caused an increase in $R_{p}$ values at the temperature range of $293-303 \mathrm{~K}$, but the value was decreased with increasing temperature, as shown in Table-2.

\subsection{Kinetic parameters for the corrosion process}

The results of the corrosion kinetic parameters are listed in Table-3, Gr.23 coating by Sr/Mg-HA before and after MAO treatment caused an increase in $E_{a}$ values from 6.0205 to 16.845 and 7.155 $\mathrm{kJ} . \mathrm{mol}^{-1}$, respectively. Figure-3 shows the values of $\log \mathrm{i}_{\text {corr }}$ plotted against reciprocal temperature for the corrosion of uncoated and coated Gr.23 by $\mathrm{Sr} / \mathrm{Mg}-\mathrm{HA}$ before and after MAO treatment.

Table 3-Kinetic and thermodynamic parameters for Gr.23 in artificial saliva at different temperatures in the range of $293-323 \mathrm{~K}$

\begin{tabular}{|c|c|c|c|c|c|c|c|c|}
\hline & \multicolumn{4}{|c|}{$\Delta \mathrm{G}^{*} / \mathrm{kJ} . \mathrm{mol}^{-1}$} & \multirow{2}{*}{$\begin{array}{l}\Delta \mathrm{H}^{*} / \mathrm{kJ} . \\
\mathrm{mol}^{-1}\end{array}$} & \multirow{2}{*}{$\begin{array}{c}-\Delta \mathrm{S}^{*} / \\
\mathrm{J} \cdot \mathrm{mol}^{-1} \cdot \mathrm{K}^{-1}\end{array}$} & \multirow{2}{*}{$\begin{array}{c}\mathrm{Ea} / \mathrm{kJ} . \mathrm{m} \\
\mathrm{ol}^{-1}\end{array}$} & \multirow{2}{*}{$\begin{array}{c}\text { A x } 10^{25} \\
\text { Molecule } \\
\text { s.cm }{ }^{-2} \cdot \mathrm{S}^{-1} \\
\end{array}$} \\
\hline & 293 & 303 & 313 & 323 & & & & \\
\hline Uncoated & 68.951 & 71.180 & 73.409 & $\begin{array}{c}75.63 \\
8 \\
\end{array}$ & 3.649 & 222.88 & 6.205 & 2.4 \\
\hline $\begin{array}{l}\text { coated by } \mathrm{Sr} / \mathrm{Mg}- \\
\mathrm{HA} \text { before MAO }\end{array}$ & 72.492 & 74.479 & 76.465 & $\begin{array}{c}78.45 \\
2 \\
\end{array}$ & 14.289 & 198.65 & 16.845 & 57.4 \\
\hline $\begin{array}{c}\text { coated by } \mathrm{Sr} / \mathrm{Mg}- \\
\mathrm{HA} \text { after MAO }\end{array}$ & 72.410 & 74.724 & 77.038 & $\begin{array}{c}79.35 \\
3 \\
\end{array}$ & 4.598 & 231.44 & 7.155 & 0.856 \\
\hline
\end{tabular}

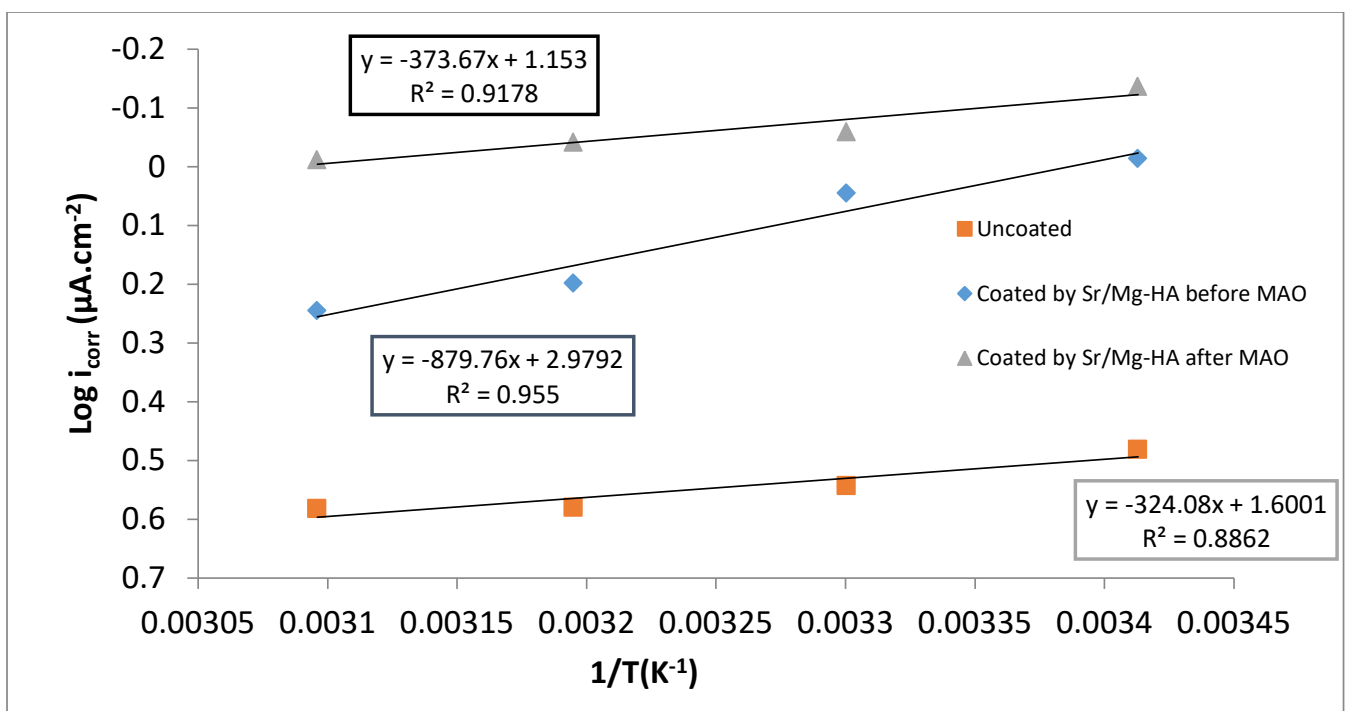

Figure 3-Arrhenius plot of $\operatorname{logi}_{\text {corr }}$ versus 1/T for the corrosion of Gr.23 in artificial saliva solution.

The values of enthalpy of activation $\left(\Delta \mathrm{H}^{*}\right)$ and entropy of activation $\left(\Delta \mathrm{S}^{*}\right)$ are illustrated in Figure-4 as obtained by the transition state in eq.(3) [19]. $\Delta S^{*}$ values, shown in Table-3, reflect the change in the order and transition state of orientation corrosion process of Gr.23. The data show slightly effected $\Delta \mathrm{S}^{*}$ values for $\mathrm{Gr} .23$ coated by $\mathrm{Sr} / \mathrm{Mg}-\mathrm{HA}$ before and after MAO treatment. 


$$
\log \frac{i_{\text {corr }}}{T}=\log \frac{R}{N h}+\frac{\Delta S^{*}}{2.303 R}-\frac{\Delta H^{*}}{2.303 R T}
$$

where $i_{\text {corr }}$ is the corrosion current density of titanium in artificial saliva which is derived from Tafel plot, $h$ is the Plank's constant, $N$ is the Avogadro number, $\Delta \mathrm{S}^{*}$ is the activation entropy and $\Delta \mathrm{H}^{*}$ is the activation enthalpy. The plot of $\log i_{\text {corr }} / T$ against reciprocal temperature demonstrates straight lines with the slope of $\left(-\Delta \mathrm{H}^{*} / 2.303 \mathrm{R}\right)$ and an intercept of $[(\log (\mathrm{R} / \mathrm{Nh})+(\Delta \mathrm{S} * / 2.303 \mathrm{R})]$, from which the values of $\Delta \mathrm{H}^{*}$ and $\Delta \mathrm{S}^{*}$ were calculated, respectively [19].

$\Delta \mathrm{H}^{*}$ is a component of activation energy, the values of which are linked to the values of $E_{a}$. The uncoated and coated Gr.23 before and after MAO treatment revealed an endothermic corrosion reaction with an increase in the value of enthalpy of activation. $\Delta G^{*}$ showed positive values and almost a small change with increasing temperature, indicating that the activated complex was not stable and the probability of its formation decreased somewhat with rising temperature [25].

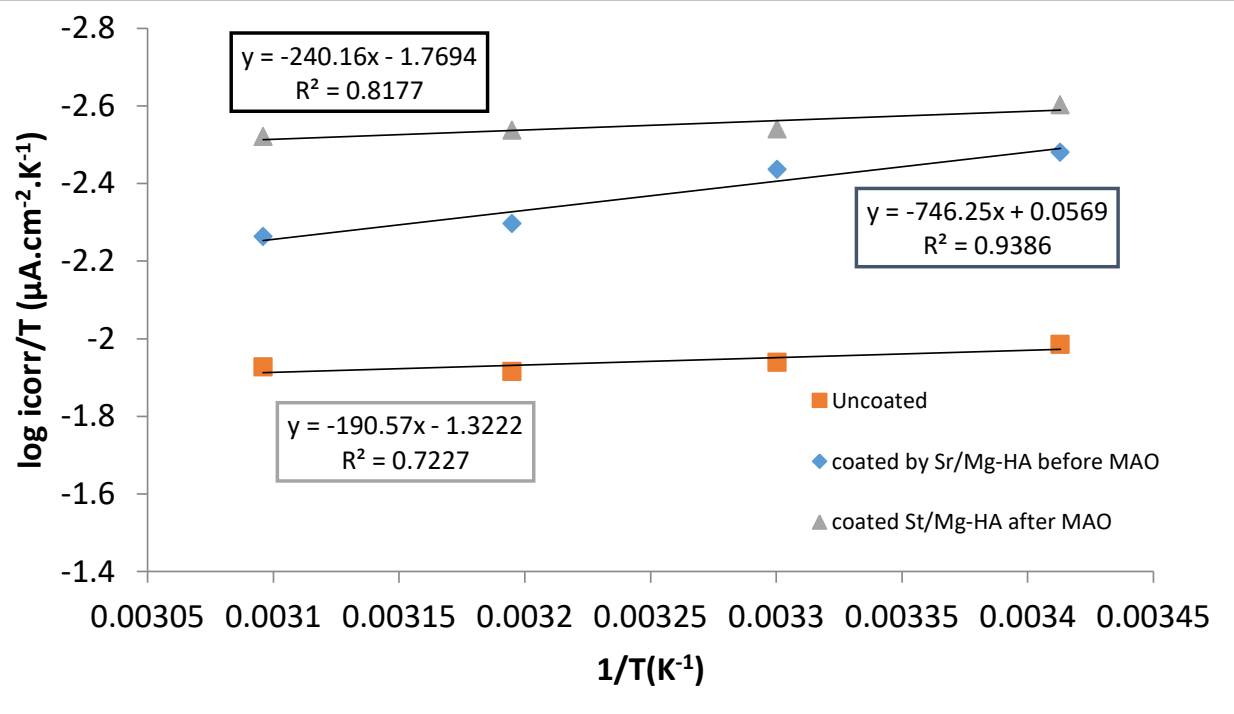

Figure 4-A plot of $\operatorname{logi}_{\text {corr }} / \mathrm{T}$ Vs $1 / \mathrm{T}$ for the corrosion of Gr.23 in artificial saliva.

\subsection{Chemical Structure and Morphology of Coating}

SEM images showing surface morphologies for coated Gr.23 by Sr/Mg-HA before and after MAO treatment were analyzed (Figure-5), It is clear from Figure-(5a) that the coating was mainly continuous, uniform and composed of needle-like crystals. White spot-like $\mathrm{Sr}$ and $\mathrm{Mg}$ nanoparticles were sparsely dispersed in the coating, as proved by EDS point detection.

Figure-(5b) shows continuous, uniform and crack-free $\mathrm{Sr} / \mathrm{Mg}-\mathrm{HA}$ after MAO coating. This image demonstrates some globular and flake shape HA deposited_in irregular manner on the surface of the Gr.23 after MAO. The average particles size of the coating was equal to 37.62 and $47 \mathrm{~nm}$ before and after MAO treatment, respectively. The particles of Sr/Mg-HA deposited on the treated Gr.23 after MAO were larger than those before MAO. The size difference in the particles size of the coatings also indicated that the nucleation and growth conditions were different on the surface samples. The thickness of the coating was $3.62 \mu \mathrm{m}$, as revealed by the cross-sectional SEM micrograph shown in Figure-6. 

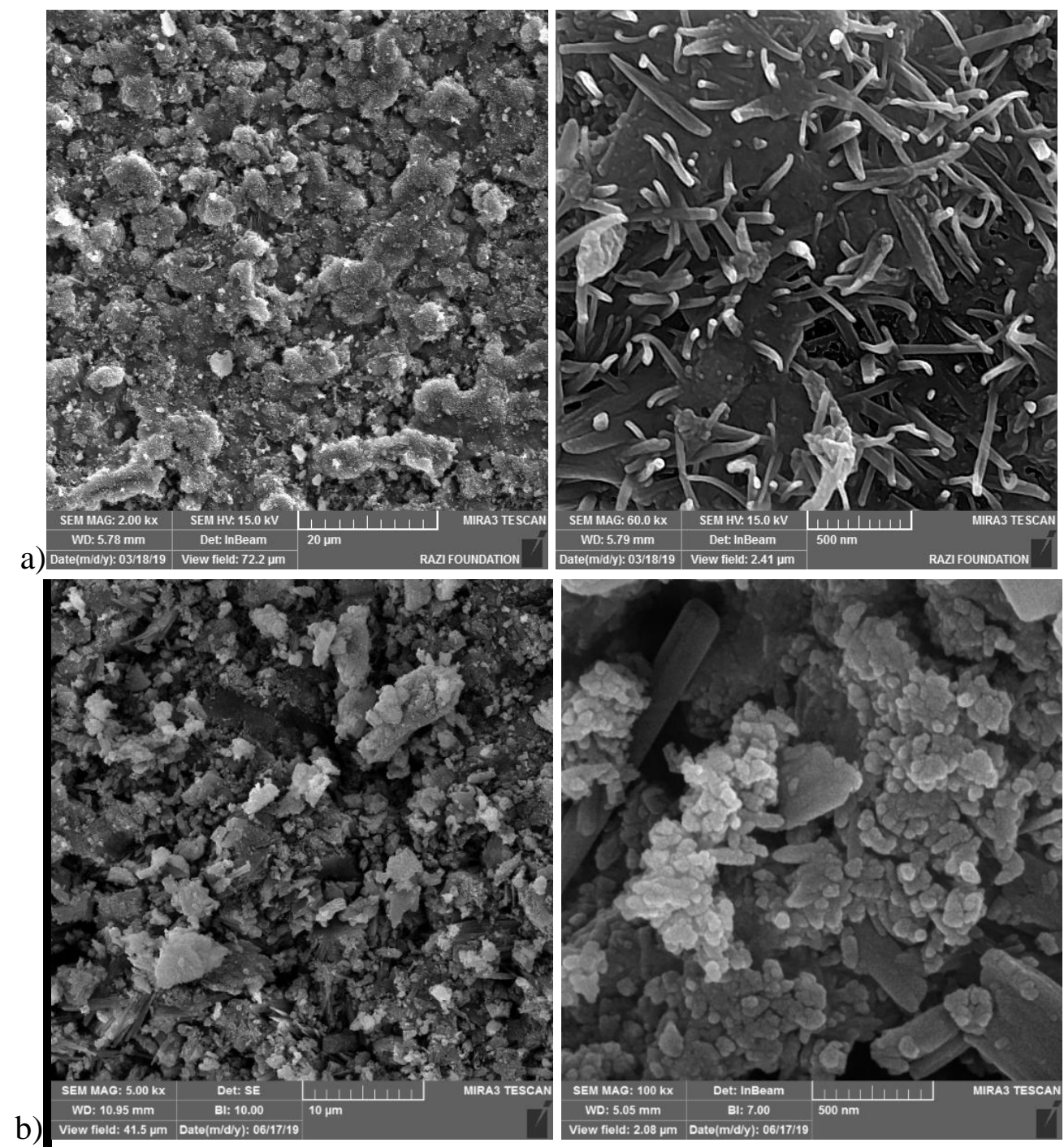

Figure 5-Scanning electron micrographs of $\mathrm{Sr} / \mathrm{Mg}-\mathrm{HA}$ deposited on $\mathrm{Gr} .23$ (a) before and (b) after MAO treatment.

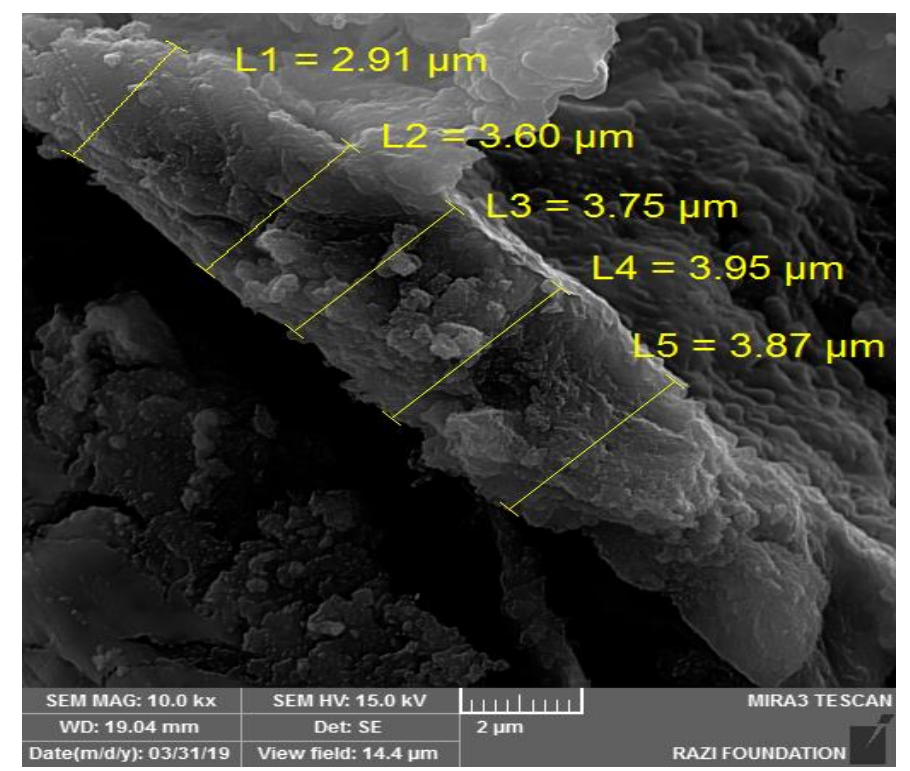

Figure 6-Cross section scanning electron micrographs of Sr/Mg-HA deposited on Gr.23 before MAO treatment. 

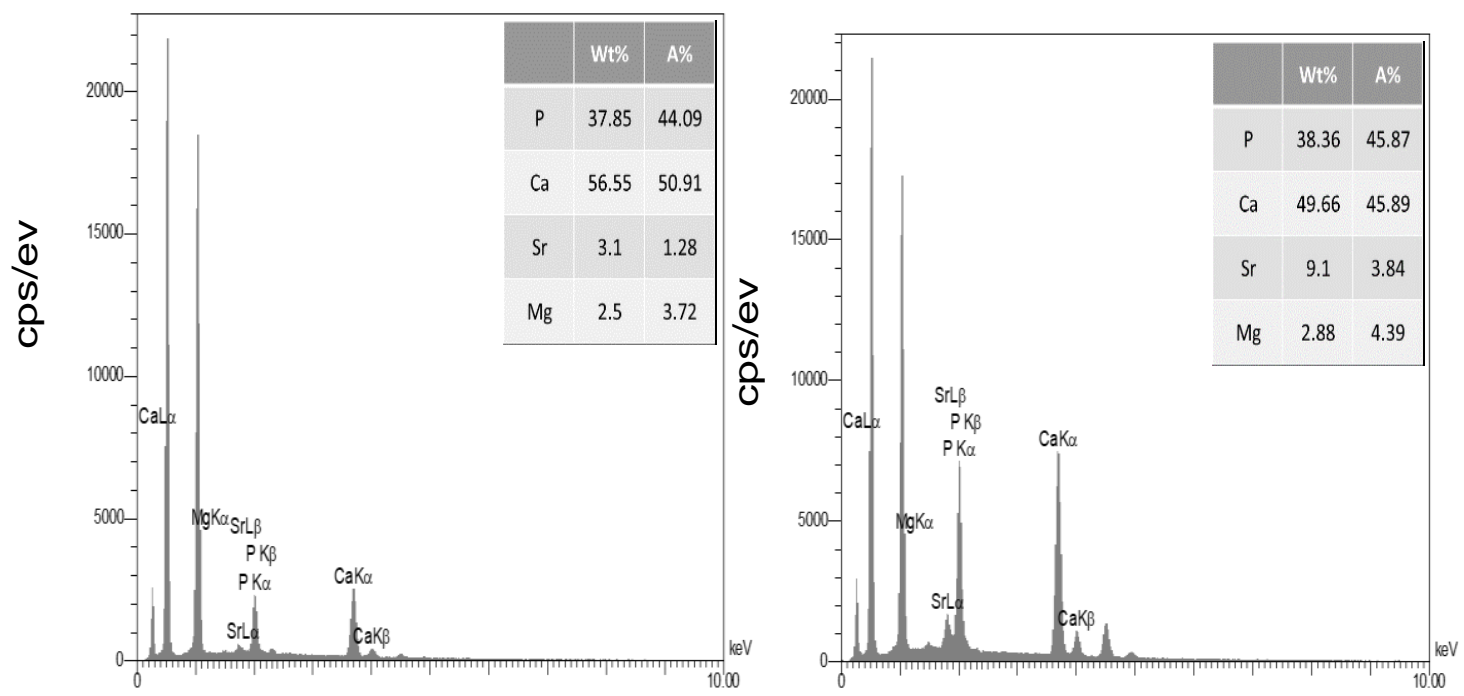

Figure 7-EDS spectra of Sr/Mg-HA coating on Gr.23 a)before and b)after MAO treatment.

The data in Figure-7 show that the values of the $\mathrm{Ca} / \mathrm{P}$ ratio of $\mathrm{HA}$ and $\mathrm{Sr} / \mathrm{Mg}-\mathrm{HA}$ coating on Gr.23 before and after MAO treatment were 1.15 and 1, respectively, which were remarkably lower than the expected ratio. The observed percentages of $\mathrm{Sr}$ and $\mathrm{Mg}$ ions were higher in $\mathrm{Gr} .23$ coated by $\mathrm{Sr} / \mathrm{Mg}$ $\mathrm{HA}$ after MAO than those before MAO treatment. This might suggest the incorporation of $\mathrm{Sr}$ and $\mathrm{Mg}$ ions in the porous structure on the surface of titanium as a result of MAO treatment.

XRD patterns of the Sr/Mg-HA coatings are shown in Figure-8. The peaks of titanium are evident in all the patterns. The overall diffraction patterns are in agreement with those reported by the current literature [26-29], showing the characteristic peaks of HA [28]. The pattern for Gr.23 coated with $\mathrm{Sr} / \mathrm{Mg}-\mathrm{HA}$ after MAO is less intense and experienced a slight shift when compared with the coated alloy after MAO.

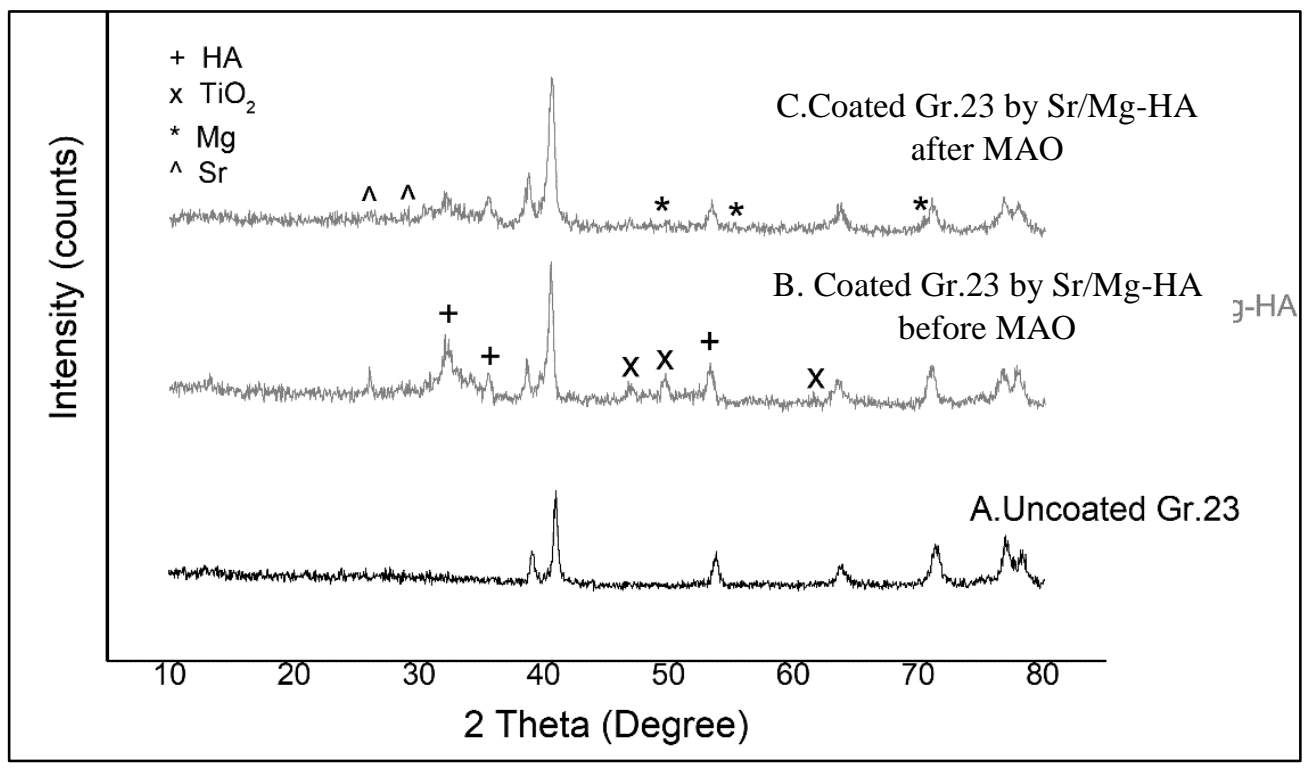

Figure 8-XRD pattern of Gr.23; (A) uncoated, (B) coated by Sr/Mg-HA before MAO, and (C) coated by $\mathrm{Sr} / \mathrm{Mg}-\mathrm{HA}$ after MAO.

FT-IR was used as a complementary technique to XRD and EDS analyses and confirmed the chemical changes in HA after the addition of ions. FT-IR spectra for the Sr/Mg-HA coatings as dried powders, presented in Figure-9, indicated the vibrational modes of $\mathrm{PO}_{4}$ groups at 499, 526, 987 and $1060-1134 \mathrm{~cm}^{-1}$ and an $\mathrm{OH}$ group at $638 \mathrm{~cm}^{-1}$ (Librational mode, $v \mathrm{~L}$, of hydroxyl groups $\mathrm{OH}^{-}$) [30] and 3492 , 3544at $\mathrm{cm}^{-1}$ (Stretching mode, $v \mathrm{~s}$, of hydroxyl groups $\mathrm{OH}^{-}$) [31] of the apatite phase for the 
coated powder [32]. The presence of adsorbed water could also be detected from FT-IR spectra in the region around 3188-3402 $\mathrm{cm}^{-1}$ [32].

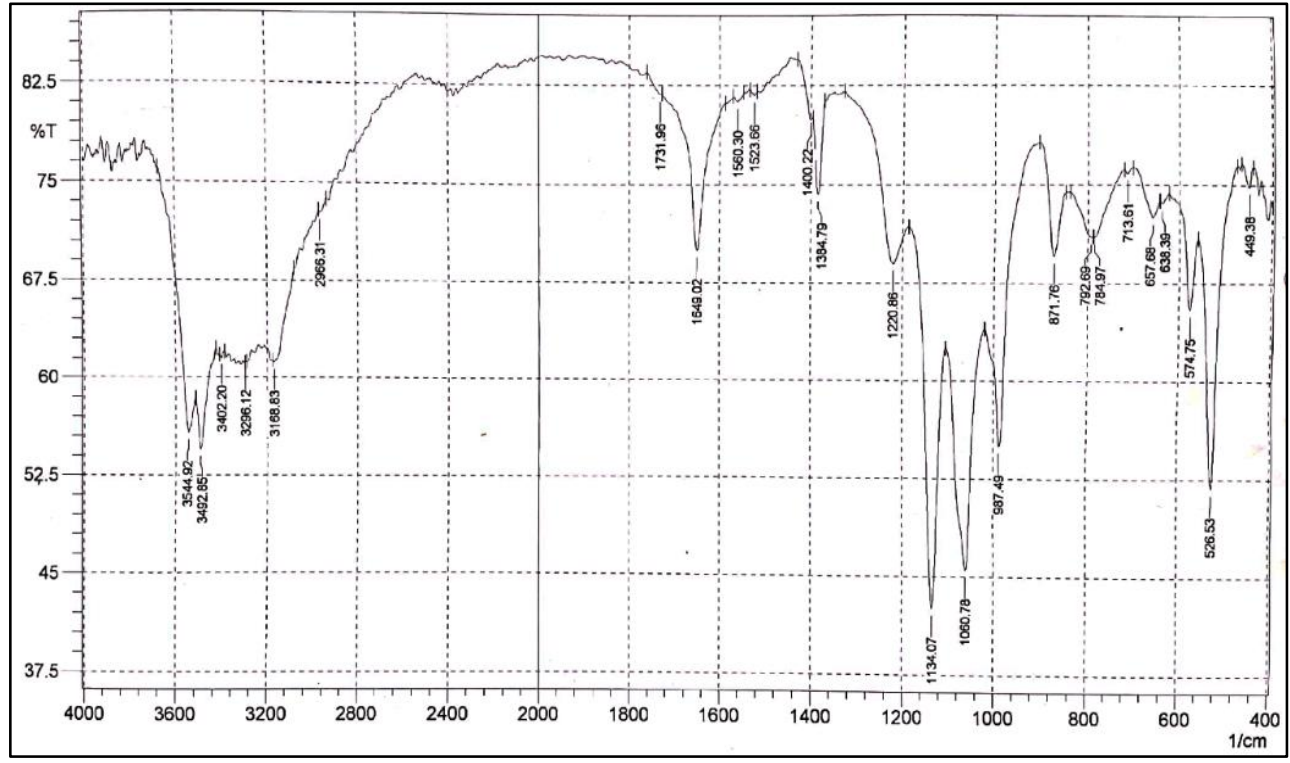

Figure 9-FT-IR spectra for coating of $\mathrm{Sr} / \mathrm{Mg}-\mathrm{HA}$.

\subsection{Adhesion Test}

Excellent adhesion of a $\mathrm{Sr} / \mathrm{Mg}-\mathrm{HA}$ coated film on the Ti surface led to good corrosion protection for Ti alloy. Adhesion testing determines how well a coating is bonded to the Ti surface. The adhesion pull-off testing was performed for different coating types.

The values for the failure strength and the type of failure indicated that the $\mathrm{Sr} / \mathrm{Mg}-\mathrm{HA}$ coating after MAO treatment reached to $1.61 \mathrm{MPa}$, which revealed stronger adhesive properties those of the coating before MAO treatment (1.79 MPa).

\subsection{Antimicrobial Activity}

With the expanding rate of microbial species in the oral cavity which are becoming resistant to present antibiotics, many studies have attempted to provide effective antimicrobial agents with low cost. Such problems have led to the resurgence in the use of metal-based antiseptics which are applicable to broader spectrum of bacteria, with far lower susceptibility to induce resistance than common antibiotics.

The results of the antibacterial activity of $\mathrm{Sr} / \mathrm{Mg}-\mathrm{HA}$ coating against different bacteria are listed in Table-4. The positive control, using amoxicillin treatment, was highly effective against Gram- positive bacteria, with a lower effectiveness against Gram- negative bacteria, at $1 \mathrm{mg} / \mathrm{mL}$ concentration. The negative control treatment with DMSO did not have any activity against both Gram-positive and negative bacteria. The highest antibacterial activity for $\mathrm{Sr} / \mathrm{Mg}$-HA coating was observed against $B$. subtilis, followed by activity against $S$. aureus. The antibacterial activities of Sr/Mg-HA coating against E. coli and A. baumannii were similar to that of the positive control, as shown in Table-4.

Table 4-Antibacterial activity (zone of inhibition, $\mathrm{mm}$ ) of the $\mathrm{Sr} / \mathrm{Mg}-\mathrm{HA}$ coating

\begin{tabular}{|l|c|c|c|c|} 
& E.Coli & A. baumannii & B.subtilis & S. aureus \\
\hline Amoxicillin $(+v e)$ & 13 & 14 & 31 & 25 \\
\hline Sr/Mg-HA coating & 13 & 13 & 29 & 27 \\
\hline
\end{tabular}

Table-5 shows the antifungal activity of $\mathrm{Sr} / \mathrm{Mg}-\mathrm{HA}$ coating. The positive control, represented by Fluconazole treatment, was highly effective against Candida species at the concentration of $1 \mathrm{mg} / \mathrm{ml}$. The antifungal activity of the coating was tested against four Candida species ( $C$. albicans, $C$. tropicalis, C. glabrata, and C. parapsilosis) by well diffusion method. The inhibition zone was observed in $\mathrm{Sr} / \mathrm{Mg}-\mathrm{HA}$ coating against $C$. albicans and $C$. glabrata, while no antifungal activity was observed against $C$. tropicalis and C. parapsilosis, as shown in Table-5. 
Table 5-Antifungal activity (zone of inhibition, $\mathrm{mm}$ ) of the $\mathrm{Sr} / \mathrm{Mg}-\mathrm{HA}$ coating

C. albicans

C. tropicalis

C. glabrata

C. parapsilosis

Fluconazole (+ve)
Sr/Mg-HA coating

28

22

22

22

\section{Conclusions}

Electrochemical deposition of Sr/Mg-HA coating on Ti-6Al-4V ELI dental alloy (Gr.23) after MAO treatment increased the corrosion efficiency from 67.98 to $75.87 \%$ at $293 \mathrm{~K}$ compared with that before MAO treatment. The particle size of $\mathrm{Sr} / \mathrm{Mg}-\mathrm{HA}$ deposited on the treated Gr.23 by MAO was larger than that before MAO treatment. The size difference of the particles of coating also indicated that the nucleation and growth conditions were different on the surface samples.

The adhesion strength of $\mathrm{Sr} / \mathrm{Mg}-\mathrm{HA}$ on Gr.23 was increased when coated on a surface treated by MAO. The antibacterial activity of $\mathrm{Sr} / \mathrm{Mg}$-HA coating was higher against Gram-positive bacteria than that against Gram-negative bacteria. The antifungal activity of $\mathrm{Sr} / \mathrm{Mg}-\mathrm{HA}$ coating showed activity against $C$. albicans and $C$. glabrata species, with no activity against $C$. tropicalis and $C$. parapsilosis species.

\section{References}

1. Fei, C., Hai, Z., Chen, C. and Yangiian, X. 2009. "Study on the tribological performance of ceramic coatings on titanium alloy surfaces obtained through microarc oxidation," Progress in Organic Coatings, 64: 264-267.

2. Santos-Coquillat, A., Tenorio, R.G., Mohedano, M., Martinez-Campos, E., Arrabal, R. and Matykina, E. 2018. "Tailoring of antibacterial and osteogenic properties of Ti6Al4V by plasma electrolytic oxidation," Applied Surface Science, 454: 157-172.

3. Wang, Y., Jiang, B., Lei, T. and Guo, L. 2004. "Dependence of growth features of microarc oxidation coatings of titanium alloy on control modes of alternate pulse," Materials Letters, 58:1907-1911.

4. Yerokhin, A., Nie, X., Leyland, A. and Matthews, A. 2000. "Characterisation of oxide films produced by plasma electrolytic oxidation of a Ti-6Al-4V alloy," Surface and Coatings Technology, 130:195-206.

5. Rautray, T.R., Narayanan, R., Kwon, T.Y. and Kim, K.H. 2010. "Surface modification of titanium and titanium alloys by ion implantation," Journal of Biomedical Materials Research Part B: Applied Biomaterials, 93: 581-591.

6. Rautray,T. R. Mohapatra, B. and Kim., K.-H. 2014. "Fabrication of strontium-hydroxyapatite scaffolds for biomedical applications," Advanced Science Letters, 20: 879-881.

7. Wang,Y. Wen, C. Hodgson, P. and Li.,Y. 2014."Biocompatibility of TiO2 nanotubes with different topographies," Journal of Biomedical Materials Research Part A, 102: 743-751.

8. W. Simka, A. Sadkowski, M. Warczak, A. Iwaniak, G. Dercz, J. Michalska, et al. , 2011, "Characterization of passive films formed on titanium during anodic oxidation," Electrochimica Acta, 56: 8962-8968.

9. S. Sobieszczyk and R. Klotzke. 2011. "Nanotubular titanium oxide layers for enhancement of bone-implant bonding and bioactivity," Advances in Materials Sciences, 11: 17-26.

10. T. R. Rautray, R. Narayanan, T.-Y. Kwon, and K.-H. Kim. 2010. "Accelerator based synthesis of hydroxyapatite by MeV ion implantation," Thin Solid Films, 518: 3160-3163.

11. K. Raja, G. Craviso, M. Misra, A. Raichur, and A. Kar. 2008. "Development of Novel Biocompatible Hydroxyapatite Coated Nanotubular Titania for Implant Application," Advances in Bioceramics and Porous Ceramics: Ceramic Engineering and Science Proceedings, 29(7): 227237.

12. S. C. Cox, P. Jamshidi, L. M. Grover, and K. K. Mallick. 2014. "Preparation and characterisation of nanophase $\mathrm{Sr}, \mathrm{Mg}$, and $\mathrm{Zn}$ substituted hydroxyapatite by aqueous precipitation," Materials Science and Engineering: C, 35: 106-114.

13. V. Aina, L. Bergandi, G. Lusvardi, G. Malavasi, F. E. Imrie, I. R. Gibson, et al. . 2013. "Srcontaining hydroxyapatite: morphologies of HA crystals and bioactivity on osteoblast cells," Materials Science and Engineering: C, 33: 1132-1142. 
14. S. Aryal, K. Matsunaga, and W.-Y. Ching. 2015. "Ab initio simulation of elastic and mechanical properties of Zn-and Mg-doped hydroxyapatite (HAP)," Journal of the mechanical behavior of biomedical materials, 47: 135-146.

15. M. Kavitha, R. Subramanian, R. Narayanan, and V. Udhayabanu. 2014, "Solution combustion synthesis and characterization of strontium substituted hydroxyapatite nanocrystals," Powder technology, 253: 129-137.

16. A. Farzadi, F. Bakhshi, M. Solati-Hashjin, M. Asadi-Eydivand, and N. A. abu Osman. 2014. "Magnesium incorporated hydroxyapatite: Synthesis and structural properties characterization," Ceramics International, 40: 6021-6029.

17. Y. Yajing, D. Qiongqiong, H. Yong, S. Han, and X. Pang, 2014, "Magnesium substituted hydroxyapatite coating on titanium with nanotublar $\mathrm{TiO} 2$ intermediate layer via electrochemical deposition," Applied Surface Science, 305: 77-85.

18. S. Meyer, R. Gorges, and G. Kreisel. 2004. "Preparation and characterisation of titanium dioxide films for catalytic applications generated by anodic spark deposition," Thin Solid Films, 450: 276281.

19. K. A. S. Al-Saadie and H. A. Y. AlMashhadani. 2019. "Corrosion Protection of Pure Titanium Implant by Electrochemical Deposition of Hydroxyapatite Post-Anodizing," in IOP Conf. Series: Materials Science and Engineering, 12071.

20. M. Z. Ibrahim, A. A. Sarhan, F. Yusuf, and M. Hamdi. 2017. "Biomedical materials and techniques to improve the tribological, mechanical and biomedical properties of orthopedic implants-A review article," Journal of Alloys and Compounds, 714: 636-667.

21. H. A. Abbas, K. A. S. Alsaade, and H. A. Y. AlMAshhdani. 2019. "Study the Effect of Cyperus Rotundus Extracted as Mouthwash on the Corrosion of Dental Amalgam," in IOP Conference Series: Materials Science and Engineering, 012074.

22. S. Shivakumar and K. Mohana, 2013, "Studies on the inhibitive performance of Cinnamomum zeylanicum extracts on the corrosion of mild steel in hydrochloric acid and sulphuric acid media," Journal of Materials and Environmental Science, 4: 448-459.

23. M. Schorr and J. Yahalom. 1972. "The significance of the energy of activation for the dissolution reaction of metal in acids," Corrosion Science, 12: 867-868.

24. K. A. S. Al-Saadie and H. A. Y. Al-Mashhdani. 2015. "Corrosion Protection Study for Caron Steel in Seawater by Coating with $\mathrm{SiC}$ and $\mathrm{ZrO} 2$ Nanoparticles," American Journal of Chemistry, 5: 28-39.

25. R. A. Mohammed. 2014. "An investigation of electropolymerization and corrosion protection properties of polypyrrole coating on carbon steel and stainless steel," Msc, Chemistry, University of Baghdad, Iraq.

26. I. Smičiklas, A. Onjia, and S. Raičević. 2005. "Experimental design approach in the synthesis of hydroxyapatite by neutralization method," Separation and Purification Technology, 44: 97-102.

27. M. H. Santos, M. d. Oliveira, L. P. d. F. Souza, H. S. Mansur, and W. L. Vasconcelos, 2004, "Synthesis control and characterization of hydroxyapatite prepared by wet precipitation process," Materials Research, 7: 625-630.

28. S. Koutsopoulos, "Synthesis and characterization of hydroxyapatite crystals: a review study on the analytical methods. 2002." Journal of Biomedical Materials Research: An Official Journal of The Society for Biomaterials, The Japanese Society for Biomaterials, and The Australian Society for Biomaterials and the Korean Society for Biomaterials, 62: 600-612.

29. S. Kweh, K. Khor, and P. Cheang. 1999. "The production and characterization of hydroxyapatite (HA) powders," Journal of Materials Processing Technology, 89: 373-377.

30. J. Arends, J. Christoffersen, M. Christoffersen, H. Eckert, B. Fowler, J. Heughebaert, et al. . 1987. "A calcium hydroxyapatite precipitated from an aqueous solution: an international multimethod analysis," Journal of Crystal Growth, 84: 515-532.

31. F. Freund and R. M. Knobel. 1977. "Distribution of fluorine in hydroxyapatite studied by infrared spectroscopy," Journal of the Chemical Society, Dalton Transactions, 1136-1140.

32. D. Laurencin, N. Almora-Barrios, N. H. de Leeuw, C. Gervais, C. Bonhomme, F. Mauri, et al. .2011. "Magnesium incorporation into hydroxyapatite," Biomaterials, 32: 1826-1837. 